\title{
Koncept advocatus fisci. Uwagi na marginesie książki Bronisława W. Sitka „Wybrane systemy prawnej i instytucjonalnej ochrony praw i interesów państwa"
}

\author{
A concept of advocatus fisci. A Few Remarks on Bronisław W. Sitek's Book \\ "Wybrane systemy prawnej i instytucjonalnej ochrony praw i interesów państwa" \\ Концепт advocatus fisci. Комментарии в контексте книги Бронислава В. Ситека \\ «Избранные системы правовой и институциональной защиты прав \\ и интересов государства»
}

\author{
KS. ANTONI DĘBIŃSKI \\ Prof. dr hab., Katolicki Uniwersytet Lubelski Jana Pawła II \\ e-mail: antoni.debinski@kul.pl, https://orcid.org/0000-0003-0777-7448
}

\begin{abstract}
Streszczenie: Artykuł ma celu analizę monografii Wybrane systemy prawnej i instytucjonalnej ochrony praw $i$ interesów państwa autorstwa Bronisława Włodzimierza Sitka, wydaną w 2020 r. przez Wydawnictwo Difin. Praca ta, obok wstępu i wniosków końcowych, składa się z ośmiu rozdziałów, z których pierwszy poświęcony jest rozwiązaniom wprowadzonym w czasach Imperium Romanum. Kolejne rozdziały stanowią omówienie wybranych systemów ochrony państwa, tj. polskiego, austriackiego, włoskiego, hiszpańskiego, szwajcarskiego, niemieckiego oraz USA, z równoczesnym omówieniem ich historycznego rozwoju. Analizowana monografia oceniona została jako przydatna dla osób zainteresowanych zagadnieniami łączącymi się z rzymską paremią Salus rei publicae suprema lex esto.
\end{abstract}

Słowa kluczowe: ochrona interesów państwa, ochrona praw, interes publiczny

Summary: The aim of the article is to analyse a monographic study entitled Selected Systems of Legaland Institutional Protection of Rights and of the Interests of the State, written by Bronisław Włodzimierz Sitek and published by the Difin publishing house in 2020. Apart from the introduction and conclusion, the work consists of eight chapters, out of which the first one is devoted to the solutions implemented in the times of the Imperium Romanum. Subsequent chapters provide analysis on the selected systems of protecting the state, with regard to Poland, Austria, Italy, Spain, Switzerland, Germany, and the USA. Simultaneously, the historical development of said systems are also discussed. The analysed monographic study has been deemed useful for people interested in issues related to the maxim of Roman law Salus rei publicae suprema lex esto (The safety of the state is the supreme law).

Key words: protection of the interests of the state, protection of rights, public interest

Резюме: Целью статьи является анализ монографии Избранные системы правовой и институциональной защиты прав и интересов государства Бронислава Влодзимежа Ситека, опубликованной в 2020 году издательством »Difin«. Эта работа, помимо введения и заключительных выводов, состоит из восьми глав, первая из которых посвящена решениям, введенным во времена Imperium Romanum. В последующих главах рассматриваются отдельные системы государственной защиты - польская, австрийская, итальянская, испанская, швейцарская, немецкая и американская, с одновременным обсуждением их исторического развития. Анализируемая монография была оценена как полезная для тех, кто интересуется вопросами, связанными с римской паремией Salus rei publicae suprema lex esto.

Ключевые слова: защита государственных интересов, защита прав, общественный интерес 
Od czasów starożytnych kształtowały się różne modele ochrony praw i interesów państwa. Niektóre współczesne systemy owej ochrony są przedmiotem recenzowanej pracy. Publikacja wyszła spod pióra profesora Bronisława Włodzimierza Sitka, którego jednym z wiodących i chronologicznie pierwszych obszarów naukowego zainteresowania jest prawo rzymskie ${ }^{1}$. Podejmowane przez niego dotychczasowe badania dotyczyły różnorodnej problematyki, głównie z zakresu rzymskiego prawa karnego (skargi popularne na przełomie republiki i pryncypatu, kara infamii, stosowanie tortur, proces św. Pawła), rzymskiego prawa publicznego (stowarzyszenia, organizacja municypiów i kolonii w starożytnym Rzymie, ustawy municypalne), teorii prawa rzymskiego (antropologiczne fundamenty prawa rzymskiego, pojęcie sprawiedliwości). W swoich publikacjach nie pomijał kwestii recepcji ius Romanorum we współczesnych, nie tylko europejskich, systemach prawnych (związki prawa rzymskiego i prawa kanonicznego, integracja europejska a prawo rzymskie, skargi popularne w Portugalii, stosowanie infamii we współczesnych przepisach prawnych, powiązania prawa rzymskiego i polskiego prawa prywatnego). Warto zauważyć, że w swoich poszukiwaniach Autor nie zamyka się w obrębie obszaru klasycznej romanistyki prawniczej; programowo stara się przenosić wyniki badań historycznych do współczesnej nauki prawa. Efektem tak pojmowanego podejścia badawczego w jego dorobku jest interesujący wątek wpływu rzymskich rozwiązań prawnych na ustawodawstwa nowożytne; recenzowana praca, rezultat wieloletnich poszukiwań cząstkowo omawianych w licznych artykułach ${ }^{2}$, także w dużej mierze

1 Świadczy o tym dowodnie fakt, że stopnie naukowe oraz tytuł naukowy uzyskał na podstawie publikacji poświęconych problematyce prawa rzymskiego. Temat pracy doktorskiej, napisanej pod kierownictwem prof. dr. hab. Henryka Kupiszewskiego (1927-1994), brzmiał: Studia nad skargami popularnymi w prawie rzymskim przedklasycznym i klasycznym; monografia pt. Pojęcie sprawiedliwości w konstytucjach cesarskich z okresu Dioklecjana i Konstantyna Wielkiego (Kraków 2006) stała się (obok innych osiągnięć) podstawą postępowania habilitacyjnego. Tytuł profesora B. Sitek uzyskał w oparciu o rozprawę pt. Infamia w ustawodawstwie cesarzy rzymskich (Olsztyn 2003).

2 Zob. B. Sitek, Ewolucja systemu prawnej ochrony praw i interesów Stanów Zjednoczonych. Urząd Prokuratora Generalnego, Teka Komisji Prawniczej. Oddział PAN w Lublinie 2018, t. 9, nr 2, s. 387-398; tenże, Ochrona dóbr narodowych Rzeczypospolitej Polskiej po rozbiorach. Prokuratoria Generalna Królestwa Polskiego, Studia z Dziejów Państwa i Prawa 2018, t. 21, s. 113-122; tenże, System ochrony praw i interesów w Federacji Szwajcarskiej, w: Pogranicza w historii prawa i myśli polityczno-prawnej, red. D. Szpoper, P. Dąbrowski, Gdańsk-Olsztyn 2017, s. 561-572; tenże, Abogados del Estado - ochrona prawna praw i interesów publicznych w Hiszpanii, w: Między Klio a Themis. Ksiegga dedykowana profesorowi Jackowi Sobczakowi, red. J.W. Adamowski, T. Wallas, K. Kakareko, Warszawa-Poznań 2016, s. 837-849; tenże, Austriacka Prokuratoria Skarbu (Finanzprokuratur), cz. 1: Historia i struktura Urzędu, Roczniki Nauk Prawnych 2016, t. 26, nr 2, s. 177-190; tenże, Austriacka Prokuratoria, cz. 2: Kompetencje organu i jego pracownicy, Roczniki Nauk Prawnych 2016, t. 26, nr 3, s. 175-193; tenże, Avvocatura dello Stato - Rzecznik Generalny ds. ochrony praw i interesów państwa. Bezpieczeństwo ochrony praw i interesów państwa włoskiego, Journal of Modern Science 2015, nr 4/27, s. 127-146; 
mieści się $\mathrm{w}$ tak rozumianym nurcie uprawiania nauki. Dodać przy tym należy, że jej Autor ma dodatkowy, prócz naukowego, motyw i legitymację do zajęcia się tym zagadnieniem. Otóż łącząc owocnie karierę akademicką ze służbą państwową, przez kilka lat pełnił funkcję prezesa Prokuratorii Generalnej Skarbu Państwa. Bez wątpienia połączenie wiedzy teoretycznej wyniesionej ze studiów i wieloletniej pracy naukowo-dydaktycznej z umiejętnościami zdobytymi z doświadczenia podczas pracy w Prokuratorii plasują Autora w gronie najbardziej kompetentnych znawców problematyki.

Przedmiotem omawianej pracy, co już zapowiada tytuł, są niektóre systemy ochrony praw i interesów państwa. Monografia, prócz Wstępu i Wniosków końcowych, obejmuje osiem rozdziałów; pierwszy z nich stanowiący dla Autora punkt wyjścia całego wywodu (nie tylko w znaczeniu układu pracy) został poświęcony antycznej instytucji advocatus fisci. Takie ujęcie wskazuje nie tylko na rodowód naukowy B. Sitka, ale i na ważne założenie, że prototypu współczesnych systemów ochrony interesów i prawa państwa należy upatrywać w starożytnym Imperium Rzymskim, zaś archetypem owego systemu jest antyczny urząd nazwany advocatus fisci. Formalnie został on powołany do życia przez cesarza Hadriana (117-138), który modernizując państwo, m.in. przeprowadził reformę jego finansów. Przyczyną zaś utworzenia urzędu była zmiana formy i koncepcji państwa, przejście od ustroju republikańskiego do pryncypatu, w którym już nie lud rzymski (populus Romanus) był uosobieniem państwa. Ucieleśniał je cesarz (początkowo zwany princepsem), który stał się centrum władzy publicznej. Do nowej formy państwa nie przystawała także republikańska koncepcja aerarium (populi Romani) - skarbu państwa rzymskiego rozumianego jako dobro publiczne. W okresie pryncypatu podstawowym źródłem finansowania zadań państwa stał się fiscus, uważany za prywatny majątek cesarza. Przy stosunkach publicznoprawnych wobec fiskusa stosowano prawo publiczne, przy stosunkach mających charakter prywatnoprawny wdrażano zaś prawo prywatne. Dla potrzeby obrony jego praw i interesów powstał urząd nazwany advocatus fisci.

Wychodząc z takich przesłanek, uwzględniając historyczny rozwój koncepcji państwa rzymskiego (ze szczególnym uwzględnieniem myśli Cycerona), w oparciu o źródła prawa rzymskiego i literaturę przedmiotu, Autor prześledził genezę, proces konstytuowania się urzędu (w tym reformy dotyczące urzędu), jego kompetencje, zadania oraz wymogi stawiane kandydatom do jego pełnienia. Rozważania te doprowadziły do ważnej konstatacji, że „Praktyka związana z wykonywaniem

tenże, Historia ochrony prawnych interesów Skarbu Państwa w Polsce, Journal of Modern Science 2014, $\mathrm{nr}$ 4/23, s. 249-262; tenże, Deontologia prawnicza $w$ praktyce advocatus fisci i radcy Prokuratorii Generalnej Skarbu Państwa, w: Prawo karne i polityka w państwie rzymskim, red. K. Amielańczyk, A. Dębiński, D. Słapek, Lublin 2015, s. 145-157. 
funkcji advocatus fisci przyczyniła się do wytworzenia pewnych zasad obecnie obowiązujących w organizacji i działaniu systemów ochrony praw i interesów państwa. Do tych zasad należy zaliczyć: powierzenie ochrony praw i interesów państwa wyspecjalizowanym prawnikom (w Polsce radcom Prokuratorii), zakaz prowadzenia spraw przeciwko fiskusowi w okresie pełnienia funkcji, zakaz podejmowania innego zatrudnienia [...], wymóg posiadania odpowiednich kwalifikacji merytorycznych, zdrowotnych i etycznych" (s. 55). W rezultacie w rozdziale pierwszym Autor $\mathrm{z}$ jednej strony umiejętnie ukazuje ponadczasowość pewnych rozwiązań prawnych wypracowanych przez jurystów rzymskich, $\mathrm{z}$ drugiej zaś zapowiada badawczy modus operandi, przyjęty na użytek publikacji: analiza i opis modelu ochrony praw i interesów danego państwa jest powiązana $\mathrm{z}$ opisem historycznego kontekstu rozwoju danego systemu (łącznie z sumarycznym przedstawieniem historii danego państwa i jego ustroju).

W kolejnych siedmiu rozdziałach zostały przedstawione poszczególne modele ochrony praw i interesów państwa. Użycie w tytule publikacji przymiotnika „wybrane" nasuwa pytanie, jakie były zasady selekcji owych systemów, dlaczego Autor ograniczył się do modeli aktualnie realizowanych jedynie (czy aż) w siedmiu państwach? Odniesienie do tej kwestii znajdziemy we Wstępie, w którym czytamy, że „dobór państw nie jest przypadkowy” (s. 15). Wprowadzając czytelnika w meritum swojego wywodu, uzasadnienie wyboru państw Autor powiązał z klasyfikacją systemów wdrożonych w różnych państwach; przedstawił dwa porządki podziału. Pierwszy z nich wyróżnia następujące modele: zadanie ochrony prawa i interesów państwa realizowane jest przez urzędników poszczególnych organów publicznych państwa (1), przez jedno z ministerstw (2), jest zlecane adwokatom wykonującym wolny zawód (3) lub jest realizowane przez adwokatów zgromadzonych w określonej instytucji zależnej od innego organu publicznego, najczęściej ministerstwa (4). Inną kategoryzacją prezentowaną przez Autora jest podział modeli ochrony na scentralizowany (1), rozproszony (2), mieszany (3) i hybrydowy (4). Przyjmując taką typizację, zastrzegając jednocześnie, że żaden z tych modeli nie występuje w czystej formie, Autor stwierdza, że „Do państw, w których występuje system silnie scentralizowanej ochrony praw i interesów państwa, należy zaliczyć Polskę, Austrię i Szwajcarię. System rozproszony występuje w Republice Federalnej Niemiec. W końcu system mieszany występuje we Włoszech i Hiszpanii. Specyficzne rozwiązanie zaś jest w Stanach Zjednoczonych, które należy określić jako system hybrydowy" (tamże). Wyjaśnienia te, rzeczowe i przemyślane, pozostawiają jednak pewien niedosyt, przede wszystkim co do samego kryterium doboru (przy analizach nie uwzględniono Wielkiej Brytanii, mimo że, jak dodaje Autor, wzorowały się na niej Stany Zjednoczone Ameryki, których system ochrony interesów państwa został 
omówiony w pracy) i liczby państw, których systemy ochrony interesów zostały wytypowane do analizy. Podobnie pewien niedostatek może powodować zbyt lakoniczne wyjaśnienie dystynkcji pomiędzy wyrażeniami „system mieszany” $i$ „system hybrydowy” (zgodnie ze słownikowym ujęciem jednym z synonimów słowa „hybrydowy” jest termin „mieszany”).

W rozdziale drugim Autor omówił system ochrony prawa i interesów w Polsce w oparciu o Prokuratorię Generalną Rzeczypospolitej Polskiej, podlegającą nadzorowi prezesa Rady Ministrów. Jej zadaniem jest ochrona praw i interesów państwa, w tym Skarbu Państwa, przed sądami i trybunałami krajowymi oraz międzynarodowymi. Jak dowodzi Autor, przedstawiając fazy jej historycznego rozwoju, taka instytucja w formie szczątkowej istniała już w okresie I Rzeczypospolitej, kiedy to funkcjonował urząd instygatora (pierwsza wzmianka o istnieniu urzędu pochodzi z drugiej połowy XVI w.), którego zadaniem była ochrona skarbca publicznego, $\mathrm{w}$ tym występowanie $\mathrm{w}$ sprawach królewskich. Pierwszym organem sensu stricto procesowym była Prokuratoria Królestwa Polskiego, utworzona na podstawie dekretu cesarza rosyjskiego i króla polskiego Aleksandra I w 1816 r. Jej ustrój wzorowany był na rozwiązaniach austriackich; w tym kształcie Prokuratoria Królestwa Polskiego przetrwała do 1915 r. Kolejnym momentem jej funkcjonowania był okres II Rzeczypospolitej; w 1919 r. powołano do życia Prokuratorię Generalną Rzeczypospolitej Polskiej, której istnienie kontynuowano po II wojnie światowej w PRL aż do 1951 r. Po zmianie ustroju w latach osiemdziesiątych powrócono do idei restytuowania urzędu; od 2006 r. zaczął funkcjonować pod nazwą Prokuratorii Generalnej Skarbu Państwa, w 2017 r. został przekształcony w Prokuratorię Generalną Rzeczypospolitej Polskiej.

Po przedstawieniu historycznych etapów rozwoju polskiego systemu ochrony prawa i interesów państwa Autor poddał szczegółowej analizie przepisy regulujące jej zadania, strukturę organizacyjną (departamenty, prezes i wiceprezesi, referendarze i inni pracownicy). Następnie omówił funkcjonowanie organów współpracujących z prokuratorią (Sąd Polubowny przy Prokuratorii Generalnej, Komisja Rozjemcza przy Sądzie Polubownym). Autor nie uchyla się od klarownych ocen; w podsumowaniu czytamy, że obecny „model ochrony praw i interesów Rzeczpospolitej Polskiej jest dość dobrze przemyślany i wydaje się być skuteczny” (s. 102).

Rozdział trzeci został poświęcony funkcjonującemu w Republice Austrii urzędowi Prokuratora Finansowego (Finanzprokuratur), którego podstawowym zadaniem jest ochrona praw i interesów państwa o charakterze majątkowym, głównie finansowym (jego działalność skupia się na dwóch podstawowych zadaniach - doradztwie prawnym i zastępstwie procesowym; adwokaci zatrudnieni w Prokuraturze mogą również prowadzić postępowania ugodowe). Podobnie jak w rozdziale 
poprzednim, Autor nakreślił szkicowo historię instytucji (sięga XII w.) na tle dziejów państwa austriackiego. Następnie omówił podstawę prawną funkcjonowania Prokuratorii, pozycję ustrojową, strukturę urzędu, zakres działania. Przedstawione analizy są szczegółowe, przywoływane dokumenty wszechstronnie charakteryzują działanie urzędu, w tym także zasady oceny i wynagradzania adwokatów i innych pracowników Prokuratorii (s. 134). Zdaniem B. Sitka austriacki „system pomocy prawnej udzielanej organom federalnym, fundacjom i funduszom publicznym, a niekiedy nawet landom i samorządom lokalnym może być pewnym wzorem dla innych państw" (s. 136).

System obrony praw i interesów państwa włoskiego, „W dużej mierze scentralizowany” i posiadający „strukturę dwupoziomową" (s. 141) jest przedmiotem czwartego rozdziału. W Italii ochrona prawa państwa jest realizowana przez Urząd Rzecznika Generalnego ds. ochrony praw i interesów państwa (tak Autor tłumaczy nazwę „Avvocatura dello Stato”), który stanowi część struktury ministerstwa sprawiedliwości. Po omówieniu historii tej instytucji począwszy od okresu przed zjednoczeniem Włoch do czasów współczesnych, prezentując model toskański (odznaczał się centralizacją reprezentacji procesowej interesów państwa) i neapolitański owej ochrony (jego cechą było powierzenie reprezentacji procesowej skarbu państwa adwokatom działającym na wolnym rynku usług prawniczych), Autor przedstawił pozycję ustrojową i strukturę urzędu adwokata państwa (Rzecznik Generalny w Rzymie, oddziały zamiejscowe umieszczone przy sądach apelacyjnych) oraz strukturę i kompetencje urzędu rzecznika Generalnego Państwa (merytoryczna kadra urzędu, adwokaci państwowi, prokuratorzy państwowi, postanowienia wspólne dla adwokatów i prokuratorów).

W rozdziale piątym został zaprezentowany współczesny system ochrony praw i interesów państwa hiszpańskiego; zadania te realizuje ulokowany w strukturze organizacyjnej ministerstwa sprawiedliwości urząd nazwany Główny Urząd Obsługi Prawnej Państwa (Abogacía General del Estado), którego korzenie sięgają pierwszej połowy XIX w. Omówienie struktury i kompetencji adwokatów państwowych stanowi treść wywodu. Autor poświęcił dużo miejsca ich statusowi (wymogi formalne dla kandydatów, procedura konkursowa, zakres kompetencji) i strukturze urzędu. W podsumowaniu Autor stwierdza, „że dość mocno scentralizowany model ochrony prawnej praw i interesów publicznych przyjęty w Hiszpanii sprawdza się bardzo dobrze od prawie dwóch wieków. Pomimo różnych zmian w strukturze Głównego Urzędu Obsługi Prawnej Państwa, wraz ze zmianą nazewnictwa i przedmiotowego ustawodawstwa, adwokaci państwowi cieszą się dużym szacunkiem i uznaniem społecznym, niezależnie od grupy politycznej rządzącej w Hiszpanii” (s. 189). 
Celem rozdziału szóstego jest ukazanie zdecentralizowanego modelu ochrony praw i interesów państwa w Szwajcarii oraz instytucji i procedur przewidzianych do ich ochrony. Jak ustala Autor, są one specyficzne, odmienne od stosowanych w innych państwach europejskich. W kraju Helwetów bowiem na przestrzeni wieków wykształcił się zdecentralizowany system polityczny, oparty na tradycji wolnych księstw czy królestw. Dlatego, konkluduje Autor, „większość działań politycznych, zwłaszcza ustawodawczych, tradycyjnie podejmowanych przez naczelne organy władzy w innych państwach europejskich, w Szwajcarii pozostały w gestii władz kantonalnych i gminnych" (s. 192). Wskutek tego, jak ocenia B. Sitek, system ochrony praw i interesów w Szwajcarii ,jest raczej systemem zdecentralizowanym, na czele którego stoi organ kontrolny i koordynujący, jakim jest Eidgenössischen Finanzverwaltung. Świadczy o tym przeniesienie obowiązku ochrony praw i interesów publicznych na poziom kantonu, a nawet i gminy" (s. 209). Z kolei sprawy, w których Federacja występuje jako strona, „rozstrzygane są przez organy wydające decyzję administracyjną lub też przez Trybunał Federalny w sprawach cywilnych" (tamże).

Zbudowany dwutorowo system ochrony praw i interesów Republiki Federalnej Niemiec został przedstawiony w rozdziale siódmym. Zgodnie $\mathrm{z}$ unormowaniami w obrębie uprawnień co do działań państwa jako podmiotu prawno-prywatnego system ten jest rozproszony. Wedle tych założeń każdy organ władzy publicznej, federalny czy związkowy, ponosi odpowiedzialność cywilnoprawną za podejmowane działania, podobnie jak każdy obywatel. W celu realizacji tych założeń, w ramach poszczególnych urzędów funkcjonują działy zatrudniające adwokatów, którzy prowadzą obsługę prawną. Podstawę prawną dla ochrony prawa i interesów poszczególnych organów stanowią przepisy kodeksu cywilnego (Bürgerliches Gesetzbuch) i kodeksu postępowania cywilnego (Zivilprozessordnung). Odmiennie kształtuje się system ochrony praw i interesów Federacji Niemieckiej w obszarze działań w sferze spraw określanych jako interes publiczny (öffentliche Interesse) lub interes federacji (Bundesinteresses). Dla ochrony interesu publicznego został ustanowiony Rzecznik Interesu Publicznego (Vertreter des Bundesinteresses beim Bundesverwaltungsgericht), formalnie umiejscowiony w strukturze ministerstwa spraw wewnętrznych, którego zadaniem jest włączanie się do każdego postępowania toczącego się przed Federalnym Sądem Administracyjnym, w którym występuje jakiś interes publiczny; o zamiarze przystąpienia musi informować rząd federalny oraz sąd.

Ósmy, ostatni rozdział obejmuje historię organizacji i funkcjonowania systemu prawnej ochrony praw i interesów Stanów Zjednoczonych Ameryki, który jest powiązany ściśle z urzędem Prokuratora Generalnego (Attorney General), który jest nominowany przez prezydenta i zatwierdzony przez Senat i jest członkiem gabinetu. 
Jak ustala B. Sitek, system utworzony w USA, chociaż jest wzorowany na angielskim modelu, posiada własną charakterystykę i historię, która jest odzwierciedleniem amerykańskiego sposobu tworzenia instytucji i określania ich kompetencji. Podstawową cechą amerykańskiego systemu ochrony praw i interesów państwa jest zachowanie ciągłości, pomimo zachodzących ewolucyjnie zmian, oraz wypracowywanie i respektowanie dialogu pomiędzy najważniejszymi organami w państwie. Stąd, począwszy od 1779 r. do czasów współczesnych, był to okres powolnego kształtowania się struktury i kompetencji Attorney General (pełni funkcję podobną do Ministra Sprawiedliwości w Polsce i w mniejszym stopniu podobną do Prokuratora Generalnego w Polsce), który stoi na czele Departamentu Sprawiedliwości (szeroko rozbudowana strukturalnie i personalnie instytucja naczelna państwa). Inną cechą charakterystyczną dla amerykańskiego modelu ochrony praw i interesów państwa jest połączenie w jednej instytucji spraw administracyjnych, karnych i cywilnych (s. 225); Prokurator Generalny jest odpowiedzialny za nie, jeśli występuje w nich interes Stanów Zjednoczonych Ameryki.

W podsumowaniu należy dodać, że poszczególne rozdziały zamieszczone w pracy stanowią oddzielne całostki; to spostrzeżenie potwierdza fakt, że wywód zamieszczony w każdym z nich został poprzedzony wprowadzeniem i zamknięty wnioskami. Do każdego rozdziału Autor dołączył bibliografię (wykaz skrótów, literatura, źródła, dokumenty i - niekiedy - orzecznictwo). Przy takiej konstrukcji tym bardziej istotnego znaczenia nabierają rzeczowe konkluzje wynikające z całego wywodu zamieszczone we Wnioskach końcowych, w których Autor na bazie kompetentnie przeprowadzonych badań dokonał porównania tych systemów. Najpierw zestawił podobieństwa, którymi są następujące elementy: współczesne państwa posiadają zorganizowane systemy ochrony ich praw i interesów, organizacja i funkcjonowanie tych systemów mają uwarunkowania historyczne lub są powiązane z rozwojem historycznym danego państwa, za obrazę prawa pracownikom takich organów grozi odpowiedzialność dyscyplinarna, w wielu kwestiach zastępstwo procesowe państwa przez te organy jest obowiązkowe. $Z$ kolei różnice dotyczą zakresów przedmiotowych ochrony praw i interesów państwa, systemów naboru i szkolenia pracowników (najczęściej adwokatów) zatrudnionych w tych urzędach, systemu i poziomu wynagradzania prawników, pozycji prawnej (umieszczenie) w strukturze państwa organów odpowiedzialnych za ochronę praw i interesów państwa (najczęściej jednostki te mieszczą się w ministerstwie finansów, sprawiedliwości lub podlegają Prezesowi Rady Ministrów; tamże). Owo zestawienie umożliwiło zredagowanie odpowiedzi na postawione we Wstępie pytanie co do możliwości stworzenia teoretycznego, optymalnego modelu systemu ochrony praw i interesów państwa (s. 16). Takiego rozwiązania, jakim byłoby zbudowanie jednego 
uniwersalnego modelu, Autor nie dostrzega, przede wszystkim dlatego, że „Różnorodność systemów jest [...] efektem rozwoju historycznego i obecnych uwarunkowań politycznych, gospodarczych czy społecznych" (s. 226).

W rezultacie omawiana publikacja, bardzo starannie wydana przez Wydawnictwo Difin, jawi się jako rzetelne i merytoryczne studium stanowiące novum na polskim rynku wydawniczym ze względu na zakres omawianej problematyki. Również w literaturze zagranicznej nie ma opracowania, które przedstawiałoby modele prawnej i instytucjonalnej ochrony praw i interesów państwa stosowanych w Europie i Stanach Zjednoczonych Ameryki, z równoczesnym omówieniem ich historycznego rozwoju. Wywód został przedstawiony z dużą erudycją; Autor wyzyskał źródła i sięgnął do obszernej, wielojęzycznej literatury przedmiotu; swobodnie i ze znawstwem porusza się w omawianej materii, tak w jej historycznej, jak i prawnej warstwie. Z pewnością praca zyska duże zainteresowanie czytelników zaciekawionych - korzeniami sięgających do myśli starożytnych jurystów rzymskich - współczesnymi rozwiązaniami prawnymi wdrażanymi celem zabezpieczenia prawa i interesów państwa.

\section{Bibliografia}

Sitek B., Abogados del Estado - ochrona prawna praw i interesów publicznych w Hiszpanii, w: Między Klio a Themis. Księga dedykowana profesorowi Jackowi Sobczakowi, red. J.W. Adamowski, T. Wallas, K. Kakareko, Warszawa-Poznań 2016.

Sitek B., Austriacka Prokuratoria, cz. 2: Kompetencje organu i jego pracownicy, Roczniki Nauk Prawnych 2016, t. 26, nr 3.

Sitek B., Austriacka Prokuratoria Skarbu (Finanzprokuratur), cz. 1: Historia i struktura Urzędu, Roczniki Nauk Prawnych 2016, t. 26, nr 2.

Sitek B., Avvocatura dello stato - Rzecznik Generalny ds. ochrony praw i interesów państwa. Bezpieczeństwo ochrony praw i interesów państwa włoskiego, Journal of Modern Science 2015, $\mathrm{nr}$ 4/27.

Sitek B., Deontologia prawnicza w praktyce advocatus fisci i radcy Prokuratorii Generalnej Skarbu Państwa, w: Prawo karne i polityka w państwie rzymskim, red. K. Amielańczyk, A. Dębiński, D. Słapek, Lublin 2015.

Sitek B., Ewolucja systemu prawnej ochrony praw i interesów Stanów Zjednoczonych. Urzad Prokuratora Generalnego, Teka Komisji Prawniczej. Oddział PAN w Lublinie 2018, t. 9, nr 2.

Sitek B., Historia ochrony prawnych interesów Skarbu Państwa w Polsce, Journal of Modern Science 2014, nr 4/23.

Sitek B., Infamia w ustawodawstwie cesarzy rzymskich, Olsztyn 2003. 
Sitek B., Ochrona dóbr narodowych Rzeczypospolitej Polskiej po rozbiorach. Prokuratoria Generalna Królestwa Polskiego, Studia z Dziejów Państwa i Prawa 2018, t. 21.

Sitek B., Pojęcie sprawiedliwości w konstytucjach cesarskich z okresu Dioklecjana i Konstantyna Wielkiego, Kraków 2006.

Sitek B., System ochrony praw i interesów w Federacji Szwajcarskiej, w: Pogranicza w historii prawa i myśli polityczno-prawnej, red. D. Szpoper, P. Dąbrowski, Gdańsk-Olsztyn 2017.

Sitek B., Wybrane systemy prawnej $i$ instytucjonalnej ochrony praw i interesów państwa, Warszawa 2020. 